\title{
Religious Complexity in the Public Sphere: Comparing Nordic Countries (Inger Furseth, ed.). Springer, 2017'
}

\author{
Elena Stepanova \\ Institute for Philosophy and Law, Ural Branch of the Russian Academy of Sciences, \\ Ural Federal University, Yekaterinburg, Russia
}

In the contemporary world, religion holds a significant place in many people's lives, intersecting with other identities. At the same time, religion has been increasingly acknowledged as an important aspect of national and international politics, a pervasive and contentious cultural force, and a subject of significant public concern. Thus, a clear need exists for scholarly research, thoughtful conversation and an ability to reach beyond the walls of the academy to translate this research to the wider public.

Today, religions in most countries in the world are directly or indirectly involved into political activities, influencing citizen's perceptions of state government legitimacy. Religions investigate alternative strategies of the presence in mass media, as well as adopt electronic and digital media technologies, reconfiguring a practice of religious mediation. Religions are taught in various forms and measures in public schools and higher educational institutions. Religions are involved in public institutions such as hospitals, army, and prisons. In addition, the increased involvement of religion in the public sphere can be understood in the context of value changes. The implication is that we are seeing the emergence and development of both post-modern and post-material values leading in some religious contexts to anti-modern counterreactions. Religious leaders and believers are today one voice among many. This suggests the importance of putting appropriate emphasis on the agency of religious interest groups from both conceptual and empirical perspectives.

In the last decades, scholars across the globe are engaged in the discussion of religion's place on the private/public continuum and of the rationality in the public sphere. Contemporary debates on religion's place in the dichotomy of public/private extend beyond the question of religion's presence

${ }^{1}$ The work is supported by the Russian Science Foundation (RSF), grant number 17-18-01194. 
in the public sphere and address the legitimacy of admitting religious arguments in public deliberation on social and political problems of the day. Rejection of Enlightenment's myth of private religion leads to recognition that religion has always played and continues to play a significant role in public space. Religion in the modern world steps out of the private domain as it assumes the task of preserving national, ethnic or group identity, and on these grounds, it justifies its demand for the voice and rights in current discussions of social and political problems. Deprivatization of religion can be observed on individual as well as on institutional level.

In all the Nordic countries (Denmark, Finland, Iceland, Norway, and Sweden), the Lutheran majority churches were closely intertwined with the state since the Reformation in the sixteenth century until the middle of the nineteenth century. The Reformation resulted in the establishment of Evangelical Lutheran state churches, which implied that every citizen was a member. In XX century, the Nordic countries being marked by Christian (mostly Lutheran) heritage became pioneers of secularism; for most citizens, religious affiliation came to mean less and less. Today, the Nordic majority churches are characterized as semi-autonomous with different degrees of autonomy from the state. Recently, a dramatic and unexpected resurgence of religion came in the form of immigrants. The Nordic countries were largely religious monocultures until immigration grew few decades later than in most other European countries. Since then, immigration has changed the Nordic ethnic and religious landscapes and especially transformed Sweden, Norway, and Denmark into relatively diverse nations. The presence of actively religious immigrants encouraged some nonimmigrant residents of Nordic countries to think more about their own religious heritage, values, and identities. Thus, the changes taking place in the Nordic countries are similar to changes taking place in many other European countries.

The book Religious Complexity in the Public Sphere: Comparing Nordic Countries (Inger Furseth, ed., Springer, 2017) is the result of a 5-year research project "The role of religion in the public sphere. a comparative study of the five Nordic countries" (NOREL) (2009-2014)2. The research group included more than 20 scholars and $2 \mathrm{PhD}$ students from all five Nordic countries. Inger Furseth from the KIFO Institute for Church, Religion, and Worldview Research, University of Oslo (Norway) edits the volume. Contributors represent the leading Nordic universities: Aarhus University (Denmark), Uppsala University (Sweden), University of Iceland, University of Copenhagen (Denmark), University of Helsinki (Finland), University of Agder (Norway), and some others.

In the introduction to the book, Inger Furseth describes the methodology and main concepts of the research. Thus, the concept of "religion" refers to a wide variety of beliefs, practices, symbols, and social arrangements; it is not seen as unitary and homogeneous, but as constructed, given meaning, and contested in various situations (p. 12); secularity is treated as a descriptive opposite to religion in the sense that the secular refers to the temporal, profane world, or the nonreligious (p. 13). Stressing the lack of theorizing regarding the presence of multiple religious trends

${ }^{2}$ www.kifo.no/forskning/religion-in-the-public-sphere-norel/research/ 
that take place simultaneously, the concept of religious complexity is introduced in the book in order to analyze multiple religious trends in contemporary Nordic countries. Religious complexity as a meta-theoretical concept refers to the simultaneous presence of several, and sometimes contradictory, religious trends that may coexist at different levels in society. The book argues that in the Nordic countries "religious complexity consists of seemingly contradictory trends, such as a growing secularization in the populations, trends of both differentiation and dedifferentiation of religion at the state level, a growing presence of religion as a topic at the political level, a greater visibility of religion in the media, and a deprivatization of religion at the level of civil society" (p. 16). Each trend is discussed in light of different theories relating to secularization, differentiation, politicization, mediatization, and deprivatization. It is stressed that religious complexity may emerge in homogeneous societies with little diversity, as for example in a country with a dominant Protestantism that experiences different developments of religious decline, growth and change at different levels, and several religious forms at each level. The complexity frame of reference rejects the notion that social change is necessarily gradual and emphasizes ruptures and path dependence. Underlying that the mere presence or visibility of various religions does not indicate that they dominate or have authority over other institutions or individuals, the concept of religious complexity implies that multiple forms of religion coexist at different levels, so that the presence of religion may be growing in the public sphere, while the individuals simultaneously are becoming more secular, or vice versa (p. 22).

In the book, four main themes of the presence and visibility of religion in public sphere are studied: religion and state; religion on the political agenda; religion and the media; religion and civil society. In the chapter on Religion and State the authors indicate the significant shift from church-state terms (with the preference to state, established, or national churches) to religion-state ones with the consequent emphasis on religious diversity. At the same time, today, with the exception of Denmark, all the Nordic majority churches (and the Orthodox Church of Finland) have become more autonomous in relation to the state since the 1980s. The authors underline that the use of the concept of "semi-autonomous" churches (again with the exception of Denmark) places the Nordic church-state relations as parts of a larger pattern of European model of church-state relations, where individual freedom of religion (and a neutral position of the state toward various individual religious subjects) is combined with the preferential treatment of one or two religious institutions, typically the historical majority churches (pp. 89-90). The authors mention that in the Nordic countries, the Evangelical Lutheran majority churches traditionally have been important elements in the legitimization of the nation-state at official occasions such as the opening of the parliaments, national holidays, and the celebration of national heroes. The authors observe the concept of "culturalization of religion" and conclude that it may allow majority religions a presence in places from where religion is banned or regarded with suspicion.

The second theme-religion on the political agenda-is developed in relation to several aspects. Thus, the observation of party platforms shows that Christian 
Democratic parties refer to Christianity as the foundation of society and the source of core values, such as solidarity, ethics, and view of human beings; religious denominations and particularly the majority churches are seen as contributors to common welfare and part of the cultural heritage. On the contrary, the right-wing populist parties do not refer at all to religion as connected to party identity.

Reviewing the controversial issue of the same-sex marriage, in which the Nordic countries have been pioneers in making it gender-neutral, the authors of the chapter on religion and political agenda stresses the importance of the double track system, which permits both civil and religious marriages with full civil law effects. They present pro and counter arguments, and interpret the debates as a struggle over core values in society, namely, the cultural and social value of marriage, and whether such an institution should depend on religious approval or not. Generally, the analysis of debates on same-sex marriage illustrates the significance of gender and sexuality in Nordic political debates on religion: the focal points for the discussion became the relation between two core values in Nordic societies: gender and sexual equality, and religious freedom. The importance of their relation is also salient in parliamentary debates on symbols, such as the wearing of religious headgear, or on religious education.

One more aspect of political agenda-the securitization of religion-is understood as an extreme version of politicization or a process whereby politicized issues are socially constructed as a threat that requires special measures. The analysis of party platforms and parliamentary debates show how the right-wing populist parties, especially in Denmark, Norway, and Sweden, emphasize a conflict where Christianity is perceived as a religion that is linked to and helps preserve national identity, while Islam is a religion that can put national identity in jeopardy (p. 180). In general, the analysis provided in the book clearly shows that the question of how to combine a situation of religious and cultural diversity with core values in the Nordic countries as Social Democratic welfare states of universalism, generous benefit levels, and egalitarianism, is one of the most demanding challenges in contemporary Nordic politics.

Highlighting the third theme-religion and media-the authors argue that the visibility of religion in the media is of key importance when trying to understand the public role of religion: if the thesis of the return of religion to the public sphere is to be valid, religion has to be visible in the media. They critically observe the "mediatization of religion" theory and its particular characteristics in the Nordic countries, and conclude about the Nordic "paradox": the considerable and continued media presence of religion on the one hand and the diminishing commitment to organized religion, on the other (p. 201). The authors show that the attention of the media has shifted from the majority churches to Islam, especially in the religiously most diverse countries of Sweden, Norway, and Denmark. At the same time, attention has gradually shifted away from the coverage of religion as news to debates on religion often presenting religious meanings that do not necessarily follow traditional understandings. In addition, the image of religion in popular lifestyle magazines, films, and on Internet is discussed in the book in details. 
The fourth theme-religion and civil society-is observed in terms of "social capital". The authors of the book conclude that due to the looser ties to the state, most Nordic majority churches in in their statements on public policies tend to behave much in the same ways as other faith and worldview communities at national and local levels. It proves that the majority churches (except the Danish one) could be viewed as part of civil society (p. 255).

In conclusion, the editor of the book stresses the need to develop new concepts in order to analyze the religious situation in contemporary Western societies, which would go beyond the customary terms such as secularization, desecularization, or post-secularity, and be more contextualized. From the authors of the book point of view, the new concepts should take into account generational changes towards more individualized and subjective approach to religious and secular worldviews and practices. This trend can have a secularizing effect in the sense that the choice to be secular is seen as a matter for each individual, and so is the choice to remain outside any faith and worldview community; it also mean the significant shift in the presence of religion in public sphere. Other important issue is the growing diversity of the Nordic welfare states and the ways to facilitate equal and fair treatment of all, which brings religion to the forefront in politics. 